\title{
Lamivudine associated hair repigmentation and a comprehensive review on reversal canities
}

\author{
MOHAMMADREZA GHASSEMI ${ }^{1}$, ELHAM BEHRANGI ${ }^{1}$, MASOUMEH ROOHANINASAB ${ }^{1}$, AFSANEH SADEGHZADEH- \\ BAZARGAN ${ }^{1}$, NILOUFAR NAJAR NOBARI ${ }^{1}$, HABIB HASANNEJAD ${ }^{1,2^{*}}$, AZADEH GOODARZI ${ }^{1 *}$ \\ ${ }^{1} M D$., Department of Dermatology, Rasool Akram Medical Complex, Iran University of Medical Sciences, Tehran, Iran \\ ${ }^{2} \mathrm{MD}$, PhD, Kyorin University School of Medicine, Tokyo, Japan \\ ${ }^{*}$ Corresponding author: Azadeh Goodarzi*, MD, Associate Professor, Department of Dermatology, Rasool Akram Medical Complex, Iran University of Medical \\ Sciences (IUMS), Email:goodarzi.a@iums.ac.ir azadeh_goodarzi1984@yahoo.com \\ ${ }^{\star *}$ Co Corresponding author: Habib Hasannejad. Department of Dermatology, Rasool Akram Medical Complex, Iran University of Medical Sciences, Tehran, Iran
}

\begin{abstract}
Background and Objective: Hair whitening is among important cosmetic problems in both genders but more annoying between women which necessitates more research about hair repigmenting methods or probable therapeutic drugs. The objective of this research was to review the mechanisms of hair pigmentation as well as the drug-related hair repigmentation.

Methods: In this review article, we searched PubMed, Medline and Google scholar databases and reviewed all related articles in this area (hair repigmentation) since the reversal of canities has been an important cosmetic concern many years ago.

Results: No reports of changes of hair color have been identified with lamivudine in the present research. Herein can be reported as the first case of hair repigmentation following the use of lamivudine.

Conclusion: We reported a case of hair pigmentation with lamivudine for the first time that could be a desirable drug-induced side effect, also review all related articles about hair repigmention or reversal of canities. By research on probable mechanisms of drug-induced hair repigmentation, we may achieve a therapeutic strategy of hair graying as an important and highly prevalent cosmetic concern.

Keywords: Lamivudine; hair repigmentation; reversal canities; drug-induced, review
\end{abstract}

\section{INTRODUCTION}

Hair whitening is among important cosmetic problem in both genders but more annoying between women which necessitates more research about hair repigmenting methods or probable therapeutic drugs.

Lamivudine with the common name of $3 T C$ is used to treat and prevent viral diseases such as HIV/AIDS and hepatitis $\mathrm{B}$, in the case of not having other choices. As a nucleoside reverse transcriptase inhibitor, its function has been described as inhibiting the reverse transcriptase enzyme of HIV and HBV (The American Society of Health-System Pharmacists, 2016).

Lamivudine is a prescription medicine approved by the U.S. Food and Drug Administration (FDA) for the therapy of AIDS in adults and children 3 months of age and older. However, other HIV medications are always prescribed along with lamivudine. Additionally, lamivudine combined with other medications is efficient in the treatment of hepatitis B and may be included in the HIV regimen of an infected person.

In this article, we reviewed the mechanisms of hair pigmentation as well as the drug-related hair repigmentation that we summarized in Table 1.

\section{MATERIALS AND METHOD}

For the literature review on this case, we searched PubMed, Medline and Google scholar databases and included all related articles published until November 2018. Written consent was obtained from the patient for publication of this article and all related images.

\section{RESULTS}

No reports of changes of hair color have been identified with lamivudine in the present article. Herein can be reported as the first case of hair repigmentation following the use of lamivudine.

\section{CASE REPORT}

An 84-year-old man, who was known as a case of hepatitis $B$ virus HBV, from 30 years ago, on therapy with lamivudine from April 2014, presented in December 2015 with hair repigmentation over the previous month.

He denied any exogenous dye. His hair was sent for chemical examination to the Chief Chemical Examiner's laboratory. No dye could be extracted from the hair and it was proved that the pigmentation was not of exogenous origin. The darkened hair persisted during therapy and did not revert to the original white color. The drug history of the patient included: nitroglycerin, metoral, losartan, lamivudine, teriamterene- $\mathrm{H}$, betahistine, nephrovit (multivitamin), calcitriol and pantoprazole, that among them lamivudine seems to be the responsible drug chronologically (see Figures 1, 2 a, b, c).

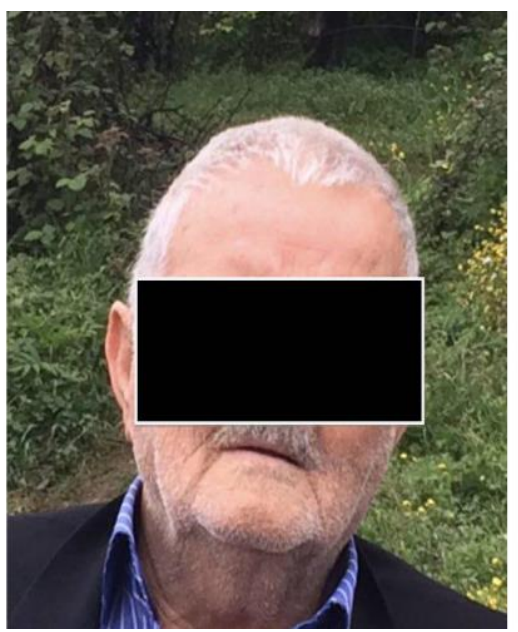

Figure 1: Before therapy with Lamivudine 


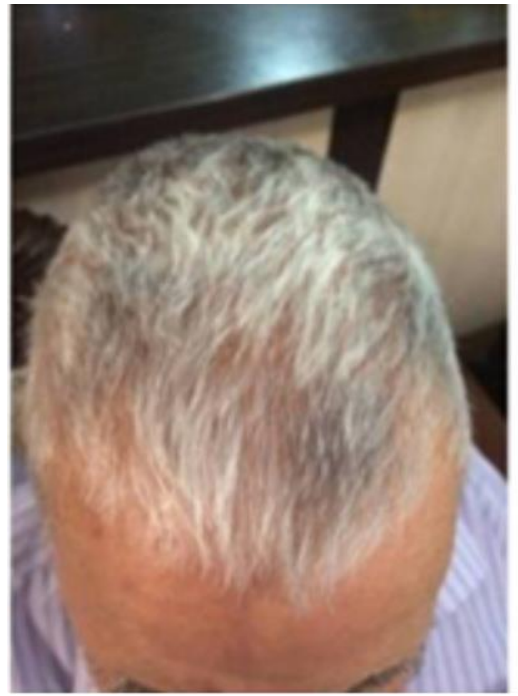

a

Figure 2a-b-c: After therapy with Lamivudine.

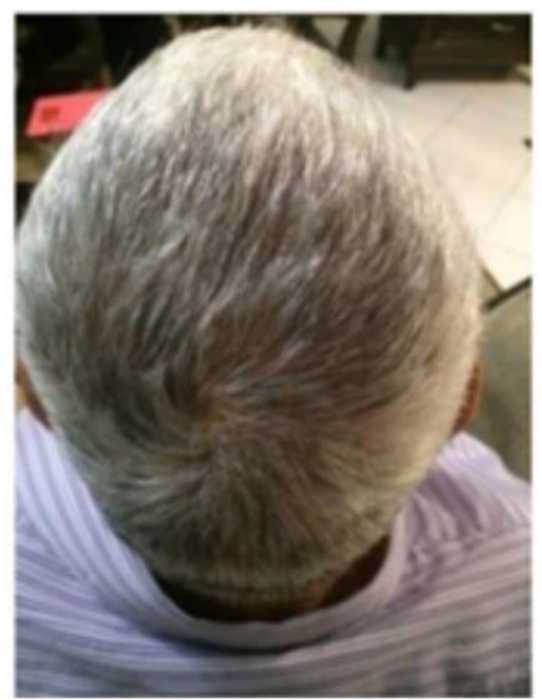

b

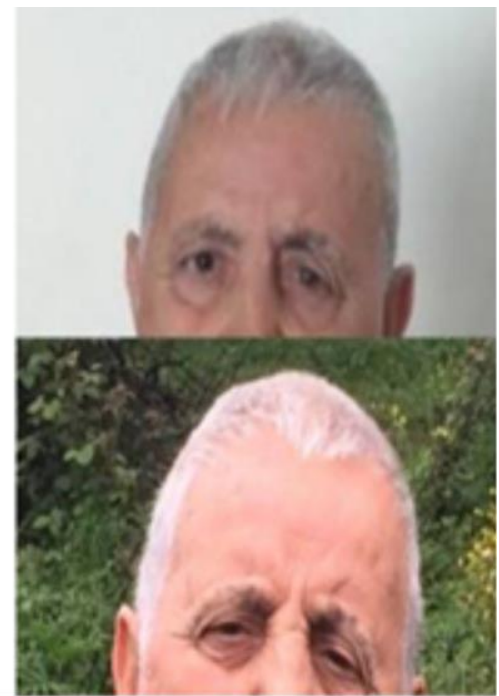

C

Table 1: Drug-induced hair repigmentation (submitted as the attachment)

\begin{tabular}{|c|c|c|}
\hline Drug & Authors & Findings \\
\hline \multirow[t]{7}{*}{$\begin{array}{l}\text { Biologic-immunotherapy } \\
\text { anti-melanoma/anti- } \\
\text { cancer }\end{array}$} & Manson et al., 2018 & $\begin{array}{l}\text { As shown in many studies, hair repigmentation related to progressive colorectal cancer and } \\
\text { Hodgkin Lymphoma in male patients who received Nivolumab treatment. Notably, the present novel } \\
\text { case appears to support the relation among a good response and HR. }\end{array}$ \\
\hline & Rivera et al., 2018 & $\begin{array}{l}\text { Based on a case series on } 53 \text { patients with lung cancer who underwent treatment with anti- } \\
\text { programmed cell death } 1 \text { (PD-1) and anti-programmed cell death } 1 \text { ligand } 1 \text { (PD-L1) antibody, } \\
\text { about } 30 \% \text { of patients experienced reversal of canities. }\end{array}$ \\
\hline & $\begin{array}{l}\text { Sebaratnam et al., } \\
2018\end{array}$ & $\begin{array}{l}\text { About probable mechanism of hair repigmentation by PD-1 and PD-L1 antibodies: it could be said } \\
\text { that, the hair follicle has a distinctive immune privilege through local expression of } \\
\text { immunosuppressive growth factors such as TGF- } \beta \text { (transforming growth factor } \beta \text { ) and down } \\
\text { regulation of major histocompatibility complex (MHC) class I molecule expression. Notably, down } \\
\text { regulation of expression of MHC class I can also be one of the majorly used devices by tumor cells } \\
\text { to avoid the immune system of the host. With activating melanogenesis as a part of the normal hair } \\
\text { cycle, the likelihood of autoimmune insult comes down due to maintenance of this immune } \\
\text { sanctuary. }\end{array}$ \\
\hline & $\begin{array}{l}\text { Correa-Selm and } \\
\text { Grichnik, } 2018\end{array}$ & $\begin{array}{l}\text { This review discusses about probable mechanism of drug-induced hair repigmentaion like local } \\
\text { changes in the inflammatory response, changes in the cellular milieu, or changes in cytokines, } \\
\text { including stem cell factors, hepatocyte growth factors, and endothelin } 3 \text {, which can be affected by } \\
\text { PD1 inhibition and consequently recruiting inactive melanocyte stem cells to produce pigments in } \\
\text { the hair follicles. }\end{array}$ \\
\hline & $\begin{array}{l}\text { Correa-Selm and } \\
\text { Grichnik, } 2017\end{array}$ & $\begin{array}{l}\text { The Krox-20 gene encodes a zinc finger transcription factor that appears to have a role in hair } \\
\text { repigmentation by multiple mechanisms. }\end{array}$ \\
\hline & Rivera et al., 2017 & $\begin{array}{l}\text { First finding, which conducted on } 14 \text { cases, showed that anti-PD-1/anti-PD-L1 therapy for lung } \\
\text { cancer can be resulted in hair repigmentation. However, in this patients treated with this kind of } \\
\text { therapy, hair repigmentation was considered as a good response marker. }\end{array}$ \\
\hline & Endou et al., 2014 & $\begin{array}{l}\text { Effects of genes indicated to affect melanocyte development is shown in a functional model of } \\
\text { mouse' hair graying; Kitl, hepatocyte growth factor (HGF) and endotheline } 3 \text { (ET3) are examples of } \\
\text { the genes among them Kitl is considered as a more efficient factor in preventing canities, compared } \\
\text { to HGF or ET3. }\end{array}$ \\
\hline \multirow[t]{6}{*}{ Chemotherapy agents } & Penzi et al., 2017 & $\begin{array}{l}\text { Repigmentation due to Brentuximab, an antibody-drug conjugate, was firstly found in this study; this } \\
\text { medication is administered for the treatment of refractory Hodgkin lymphoma and systemic } \\
\text { anaplastic large cell lymphoma, and has been approved by the FDA. }\end{array}$ \\
\hline & Dai et al., 2017 & $\begin{array}{l}\text { During treating with targeted anticancer therapies, there is a substantial risk of development of } \\
\text { pigmentary changes, especially with epidermal growth factor receptors and breakpoint cluster } \\
\text { region-abelson inhibitors. }\end{array}$ \\
\hline & Lovering et al., 2016 & $\begin{array}{l}\text { The first study of case of hair repigmentation that used a related immunomodulatory drug } \\
\text { (thalidomide) as well }\end{array}$ \\
\hline & Cheng et al., 2014 & $\begin{array}{l}\text { Hair repigmentation has been reported among side effects of erlotinib, although among desirable } \\
\text { ones. }\end{array}$ \\
\hline & Dasanu et al., 2013 & $\begin{array}{l}\text { Report of hair regimentation connecting with the application of lenalidomide as the treatment of } \\
\text { multiple myeloma in an old patient. The effect of } \\
\text { lenalidomide on follicular melanogenesis may involve removing the inhibitory effects of some } \\
\text { cytokines including IL-1, IL-6 and TNF-a. Also, certain endocrine effects of lenalidomide on the } \\
\text { hypophyseal-adrenal axis could explain its effect on hair pigmentation. We consider that } \\
\text { repigmentation of gray hair follicles would be promoted may be because of being ability of stimulate } \\
\text { migration and/or differentiation of melanocytes in lenalidomide. }\end{array}$ \\
\hline & Kudo et al., 2011 & tinib toxicity would be present as a cosmetic side effect like hair repigmentation. \\
\hline
\end{tabular}




\begin{tabular}{|c|c|c|}
\hline & Ehmann et al., 2011 & $\begin{array}{l}\text { Hair changes are among various cutaneous side-effects associated with EGFR inhibitors with long } \\
\text { time interval. }\end{array}$ \\
\hline & Wollenberg et al., 2010 & Different Hair changes could be seen with EGFR inhibitors. \\
\hline & $\begin{array}{l}\text { Galimont-Collen et al., } \\
2007\end{array}$ & $\begin{array}{l}\text { Hair changes are among cutaneous side-effects of EGFR inhibitors but are among less common } \\
\text { complications. }\end{array}$ \\
\hline & Etienne et al., 2002 & $\begin{array}{l}\text { During treatment, } 9 \text { of } 133 \text { cases ( } 5 \text { men and } 4 \text { women; median age, } 63.4 \text { years) with chronic } \\
\text { myeloid leukemia that received treatment with imatinib, also experienced progressive } \\
\text { repigmentation of their hair (in } 8 \text { cases the effects were observed on the head, and in one case, on } \\
\text { the body and head). }\end{array}$ \\
\hline & Babu et al., 1995 & Canities reversal could be occurring during chemotherapy. \\
\hline \multirow[t]{6}{*}{$\begin{array}{l}\text { Biologic anti-psoriatic } \\
\text { agents }\end{array}$} & Rongioletti et al., 2018 & $\begin{array}{l}\text { Report of a case with repigmentation and regrowth of hair following treatment with anti-interleukin- } \\
17 \text { and secukinumab for psoriasis. }\end{array}$ \\
\hline & Di Cesare et al., 2015 & $\begin{array}{l}\text { Returning of expression of pigmentation gene with the partial manifestion of speckled lentigo-like } \\
\text { lesions in resolving plaques of psoriasis can be caused by Blockade of TNF- } \alpha \text { and IL-17 }\end{array}$ \\
\hline & Tintle et al., 2015 & $\begin{array}{l}\text { Of side effects of adalimumab, used in treating psoriasis, can be hair loss, or alopecia; no change } \\
\text { in hair repigmentaion caused by using this class of drug has been yet reported, though. }\end{array}$ \\
\hline & Wang et al., 2013 & $\begin{array}{l}\text { The synergistic efficacy on melanocytes from IL-17 and TNF- } \alpha \text {, which both inhibit pigmentation- } \\
\text { related signaling and melanin production and induce keratinocyte production of } \beta \text {-defensin-3 (an } \\
\text { antagonist for melanocortin } 1 \text { receptor), was studied. }\end{array}$ \\
\hline & Choi et al., 2013 & $\begin{array}{l}\text { An altered immune control in the hair cycle can cause hair darkening and thickening to increased } \\
\text { anagen growth phase, eliminating the inhibitory influences of IL-17 following the use of } \\
\text { secukinumab. The synthesis of antimelanogenic cytokine IL- } 6 \text { in cultured normal human } \\
\text { melanocytes may be increased by IL-17. }\end{array}$ \\
\hline & Kotobuki et al., 2012 & $\begin{array}{l}\text { In psoriasis skin lesions that over express pro-inflammatory cytokines such as IL-17 and TNF-a, a } \\
\text { reduction in pigmentation signaling and expression of pigment gene would be seen which could be } \\
\text { counteracted by treatment with TNF- } \alpha \text { and IL-17 inhibitors. }\end{array}$ \\
\hline \multirow[t]{6}{*}{ Retinoids } & Nagase et al., 2017 & $\begin{array}{l}\text { It is unclear why etretinate therapy causes hair alteration, which includes repigmentation and } \\
\text { curling; it would be due to the efficacy of retinoids on melanocyte stem cells located in the } \\
\text { bulge/sub-bulge area and with follicular keratinization. }\end{array}$ \\
\hline & Tengattini et al., 2015 & $\begin{array}{l}\text { A case with psoriasis that had darkening of gray hair and diffuse hyperpigmentation of the skin on } \\
\text { some areas of the head, following therapy with acitretin and UVB. }\end{array}$ \\
\hline & Ward et al., 2014 & A patient with hair repigmentation and curling on acitretin therapy. \\
\hline & Wang et al., 2011 & $\begin{array}{l}\text { UVR causes melanocyte proliferation/activation in epidermis and dermis as RXRa (ep-/-) mice } \\
\text { showed. }\end{array}$ \\
\hline & Seckin And Yildiz, 2009 & $\begin{array}{l}\text { Darkening of previously white hair in a case with psoriasis along with gaining a curly appearance } \\
\text { occurred } 6 \text { months after treatment by acitretin }\end{array}$ \\
\hline & Vesper et al.1996 & Hair re-growth and darkening associated with etretinate therapy. \\
\hline Clofazimine & Philip et al., 2012 & $\begin{array}{l}\text { Along with the expected side effect of skin pigmentation in a patient with borderline leprosy on multi } \\
\text { drug therapy, darkening of previously grey hair was observed which was persisted months after } \\
\text { therapy. }\end{array}$ \\
\hline Interferon and Ribavirin & Kavak et al., 2005 & $\begin{array}{l}\text { Presentation of hair repigmentation in a hepatitis } \mathrm{C} \text { patient, who received interferon and ribavirin } \\
\text { treatment. }\end{array}$ \\
\hline Indinavir & Terheggen et al., 2004 & A patient on indinavir therapy experienced nail, hair and skin hyperpigmentation. \\
\hline Latanoprost & Bellandi et al., 2011 & $\begin{array}{l}\text { With using latanoprost for a long time, approximately } 3 \text { years, a PGF2 alpha eye drops } \\
\text { demonstrated repigmentation of white hair. }\end{array}$ \\
\hline Systemic steroid & Khaled et al., 2008 & hair repigmentation occurred after systemic corticosteroids in a patient with bullous pemphigoid. \\
\hline Thyroid hormone therapy & Redondo et al., 2007 & $\begin{array}{l}\text { The topical application of T3 ( thyroid hormone) can induce the entrance of the telogen phase } \\
\text { follicles into the anagen phase, which may be followed by reversing graying of the terminal hair. T3 } \\
\text { (in vitro) induced the growing of hair shaft. Follicular melanocyte might be the target cell for this } \\
\text { process. }\end{array}$ \\
\hline
\end{tabular}

\section{DISCUSSION}

Lamivudine is considered as an analogue of cytidine. Either types (1 and 2) of HIV reverse transcriptase can be inhibited by lamivudine in addition to the reverse transcriptase of HBV (The American Society of HealthSystem Pharmacists, 2016).

Canities or graying of hair is a permanent, progressive and physiological aging process caused by the gradual reduction of tyrosinase activity in melanocyteor loss of melanocytic function. Genetic factors affect age of onset and progression. The process of canities is found to be persistent and progressive, not inclusive of alopecia areata and vitiligo. Premature canities is specified as beginning of hair graying which occurs prior to the age of twenty in whites and 30 years in blacks that could be an isolated, familial or in association with severe cases of malnutrition or some other disease like autoimmune disorders (pernicious anemia, vitamin $\mathrm{B}_{12}$ and iron deficiency, thyroid dysfunction, Addison's disease) or in the setting of many premature aging syndromes or genodermatosis. There are some drugs with known effect and an unknown mechanism that may lead to hair graying or depigmentation like chloroquine, hydroxychloroquine, mephenesin, triparanol, and fluorobutyrophenone [1] .

Hair repigmentation is a possible but rare side effect of some drugs that may present with bothersome hair graying or desirable hair repigmentation like chloroquine and cancer chemotherapeutic agents as the mejor prevalent reports. Changing of hair color also has been reported by use of p-aminobenzoic acid, calcium pantothenate, anthralin, chinoform, mephenesin, minoxidil, propofol, valproic acid, and verapamil [2-4] .

Although changing hair color is not a common adverse effect of drugs, with the emerging and wide usage of new targeted therapies, this changing has become more prevalent with unknown mechanisms. Canities is not life- 
threatening but has a great impact on the quality of life of patients and adherence to treatment.

In this article, we reviewed the mechanisms of hair pigmentation [5-13] as well as the drug-related hair repimentation that we summarized in Table 1 .

In the hair growth cycle, there is a period of proliferation of melanocytes (during early anagen), maturation of melanocytes (mid to late anagen), and apoptosis of melanocyte (during early catagen). Canities is a genetic mediated, age-related decreased pigmentary potential of hair follicular unit. The aging of melanocyte may be related to reactive oxygen species, anti-oxidant dysregulation and pro/anti-apoptotic factors, causing mutations in DNA during natural aging. Moreover, canities may be a true graying or pigment dilution. The dilution is caused by decreased tyrosinase activity, diminished melanocyte-keratinocyte interactions, and defective melanocyte transfer from a reservoir in the upper outer root sheath to the surrounding dermal papilla area of hair bulb. In studies on animals, mutations in the BCL2 as an apoptotic survival factor and in melanogenic enzymes (TRP-1), have shown to be related with hair graying [12, 13]

Eu- or/and pheomelanin in the hair shaft is formed by interactions among follicular melanocytes, keratinocytes, and dermal papilla fibroblasts. An array of enzymes, structural and regulatory proteins, transporters, and receptors and their ligands, acting on the developmental stages, cellular, and hair follicle levels regulate the follicular melanogenesis (dominantly in anagen period) and melanogenic activity. The important regulators are melanocortin 1 receptor (MC1R), adrenocorticotropic hormone, melanocyte-stimulating hormone, agouti protein ligands (in rodents), c-Kit, and the endothelin receptors with their ligands [9] .

Oxidative stress is among the most important theories of grayi ng [5]. Follicular melanocytes are more susceptible to aging than epidermal melanocytes, so canities could be explained by biologic diversities in the epidermal and follicular microenvironments [11] .

In general, melanocyte and melanin depletion due to reactive oxygen species, impaired antioxidant process and a rejuvenation failure of melanocyte stem cells are supposed to be the mechanisms of graying [10] .

The rule of 50 says that $50 \%$ of the people have $50 \%$ hair graying at the age of 50 ; also based on a new definition, premature graying/canities appears prior to the age of twenty in Caucasians, prior to twenty-five in Asians, and prior to thirty in Africans. $\mathrm{PH}$ change, melanosomal cysteine levels, level of trace metal ions, vitamin $\mathrm{B}_{12}$, folic acid, vitamin $D_{3}$, and oxidative stress are suggested to be the etiological factors of canities. Different topical preparations that conatin phytic acid, amino acids, peptides, acetyl hexapeptide-1, melitane, capixyl, pea proteins, etc. can be found in the market with the aim of therapy. Currently, topical liposome targeting melanins, genes, and hair follicle-specific proteins also novel techniques have been discussed for therapeutic and cosmetic modification of hair $[14,8]$.

In this review, we found that biologic-immunotherapy anti-melanoma/anti-cancer agents [15-20], chemotherapy agents [21-31], biologic anti-psoriatic agents33-38, retinoids [32-37], and other drugs like clofazimine [38] , interferon and ribavirin [39], indinavir [40], latanoprost48, systemic steroid49, and thyroid hormone therapy50 have been reported being in association with hair repigmentation.

Other than specific hair repigmentation related to biologic-immunotherapy anti-melanoma/anti-cancer agents, mentioned above, there are many other articles focusing on associated dermatologic adverse effects of these drugs in the skin and its appendageal organs (like hair and nail), among them hair color change and canities reversal could be seen frequently [41-46] .

Furthermore, there are also many reports of non-drug related hair repigmentation such as the presence of adjacent melanoma [47-51], actinic granuloma [52] , epilation [53], hair transplant [54], zoster [55] , spontaneous [56-59] and X-ray irradiation or electron beam exposure [60] .

Genes are known to be affected by the development of melanocytes, such as Kitl, hepatocyte growth factor (HGF) and endotheline-3 (ET3) which can be altered in many settings like hepatitis or by drugs, using in its therapy. Stem cell factors, hepatocyte growth factors, and endothelin-3 can be potentially triggered by inhibition of PD1 and, consequently, recruit inactive melanocyte stem cells to produce pigments in the hair follicles. [14, 16, 39] .

The authors of this study are really interested in various feilds of hair disorders and provable associations and now we tried to present a unique case of hair canities reversal [61-65]. Thus, in our case, both hepatitis and lamivudine therapy could be responsible for the reversal of canities. By research on probable mechanisms of druginduced hair repigmentation, we can achieve to find a therapeutic strategy of hair graying as a very important and highly prevalent cosmetic concern. Thus, in our case, both hepatitis and lamivudine therapy could be responsible for the reversal of canities. By research on probable mechanisms of drug-induced hair repigmentation, we can achieve to find a therapeutic strategy of hair graying as a very important and highly prevalent cosmetic concern.

\section{CONCLUSION}

We reported a case of hair pigmentation with lamivudine for the first time that could be a desirable drug-induced side effect, also review all related articles about hair repigmention or reversal of canities. By research on probable mechanisms of drug-induced hair repigmentation, we may achieve a therapeutic strategy of hair graying as an important and highly prevalent cosmetic concern.

Acknowledgement: We would like to show our gratitude to the Rasool Akram Medical Complex Clinical Research Development Center (RCRDC) for its technical and editorial assists.

Funding Source: No funding was received for the preparation of this manuscript.

Conflict of interest: None declared.

Ethics approval: Not applicable.

Consent to participate: Not applicable.

Consent for publication: Written consent was obtained from the patient for publication of this manuscript and all related images. To keeping ethical principles, name of the 
patient was not pointed in the paper and his eyes have been covered in the photos.

\section{REFERENCES}

1. Tobin DJ, Cargnello JA. Partial reversal of canities in a 22year-old normal Chinese male. Arch Dermatol. 1993;129(6):789-91.

2. Bublin JG, Thompson DF. Drug-induced hair colour changes. Journal of clinical pharmacy and therapeutics. 1992;17(5):297-302.

3. Gerstner T, Lipinski C, Longin E, König S. Valproate-induced change in hair color. J Am Acad Dermatol. 2008;58(2 Suppl):S63-4.

4. Kakunje A, Prabhu A, Sindhu Priya ES, Karkal R, Kumar P, Gupta N, Rahyanath PK. Valproate: It's Effects on Hair. Int J Trichology. 2018;10(4):150-3.

5. Arck PC, Overall R, Spatz K, Liezman C, Handjiski B, Klapp BF, Birch-Machin MA, Peters EM. Towards a "free radical theory of graying": melanocyte apoptosis in the aging human hair follicle is an indicator of oxidative stress induced tissue damage. FASEB journal : official publication of the Federation of American Societies for Experimental Biology. 2006;20(9):1567-9.

6. Goren A, Bolanča Ž, Lotti T, Šitum M. Novel technique for repigmentation of senescence grey hair. Dermatol Ther. 2017;30(2).

7. Ricci F, De Simone C, Del Regno L, Peris K. Drug-induced hair colour changes. European journal of dermatology : EJD. 2016;26(6):531-6.

8. Sehrawat M, Sinha S, Meena N, Sharma PK. Biology of hair pigmentation and its role in premature canities. Pigment International. 2017;4(1):7.

9. Slominski A, Wortsman J, Plonka PM, Schallreuter KU, Paus $R$, Tobin DJ. Hair follicle pigmentation. The Journal of investigative dermatology. 2005;124(1):13-21.

10. Tobin DJ. Aging of the hair follicle pigmentation system. Int $\mathrm{J}$ Trichology. 2009;1(2):83-93.

11. Tobin DJ. Human hair pigmentation--biological aspects. International journal of cosmetic science. 2008;30(4):233-57.

12. Tobin DJ, Paus R. Graying: gerontobiology of the hair follicle pigmentary unit. Experimental gerontology. 2001;36(1):2954.

13. Van Neste D, Tobin DJ. Hair cycle and hair pigmentation: dynamic interactions and changes associated with aging. Micron (Oxford, England : 1993). 2004;35(3):193-200.

14. Correa-Selm LM, Grichnik JM. Prevention of graying: Is KROX20 the solution? Dermatol Ther. 2017;30(5).

15. Correa-Selm LM, Grichnik JM. PD1 inhibitors and hair repigmentation: $A$ desirable new side effect. Dermatol Ther. 2018;31(1).

16. Endou M, Aoki H, Kobayashi T, Kunisada T. Prevention of hair graying by factors that promote the growth and differentiation of melanocytes. J Dermatol. 2014;41(8):71623.

17. Manson G, Marabelle A, Houot R. Hair Repigmentation With Anti-PD-1 and Anti-PD-L1 Immunotherapy: A Novel Hypothesis. JAMA Dermatol. 2018;154(1):113.

18. Rivera $\mathrm{N}$, Boada $\mathrm{A}$, Bielsa $\mathrm{MI}$, Fernández-Figueras $\mathrm{MT}$, Carcereny E, Moran MT, Ferrándiz C. Hair Repigmentation During Immunotherapy Treatment With an Anti-Programmed Cell Death 1 and Anti-Programmed Cell Death Ligand 1 Agent for Lung Cancer. JAMA Dermatol. 2017;153(11):11625.

19. Rivera N, Boada A, Ferrándiz C. Hair Repigmentation With Anti-PD-1 and Anti-PD-L1 Immunotherapy: A Novel Hypothesis-Reply. JAMA Dermatol. 2018;154(1):113-4.

20. Sebaratnam DF, Rodríguez Bandera Al, Lowe PM. Hair Repigmentation With Anti-PD-1 and Anti-PD-L1
Immunotherapy: A Novel Hypothesis. JAMA Dermatol. 2018;154(1):112-3

21. Babu KG, Rasheshyam D, Lalitha N. Canities--reversal with chemotherapy. The Journal of the Association of Physicians of India. 1995;43(8):577.

22. Cheng YP, Chen HJ, Chiu HC. Erlotinib-induced hair repigmentation. Int J Dermatol. 2014;53(1):e55-7.

23. Dai J, Belum VR, Wu S, Sibaud V, Lacouture ME. Pigmentary changes in patients treated with targeted anticancer agents: A systematic review and meta-analysis. J Am Acad Dermatol. 2017;77(5):902-10.e2.

24. Dasanu CA, Mitsis D, Alexandrescu DT. Hair repigmentation associated with the use of lenalidomide: graying may not be an irreversible process! Journal of oncology pharmacy practice : official publication of the International Society of Oncology Pharmacy Practitioners. 2013;19(2):165-9.

25. Ehmann LM, Ruzicka T, Wollenberg A. Cutaneous sideeffects of EGFR inhibitors and their management. Skin therapy letter. 2011;16(1):1-3.

26. Etienne G, Cony-Makhoul P, Mahon FX. Imatinib mesylate and gray hair. The New England journal of medicine. 2002:347(6):446.

27. Galimont-Collen AF, Vos LE, Lavrijsen AP, Ouwerkerk J, Gelderblom H. Classification and management of skin, hair, nail and mucosal side-effects of epidermal growth factor receptor (EGFR) inhibitors. European journal of cancer (Oxford, England : 1990). 2007;43(5):845-51.

28. Kudo K, Fujiwara K, Tsushima M, Mizuta M, Matsuo K, Yonei T, Sato T. Toxicity manifesting as cosmetic hair alterations during erlotinib treatment. Acta oncologica (Stockholm, Sweden). 2011;50(1):146-8.

29. Lovering S, Miao W, Bailie T, Amato D. Hair repigmentation associated with thalidomide use for the treatment of multiple myeloma. BMJ case reports. 2016;2016.

30. Penzi LR, Manatis-Lornell A, Saavedra A, Fisher D, Senna MM. Hair repigmentation associated with the use of brentuximab. JAAD case reports. 2017;3(6):563-5.

31. Wollenberg A, Kroth J, Hauschild A, Dirschka T. Cutaneous side effects of EGFR inhibitors--appearance and management. Deutsche medizinische Wochenschrift (1946). 2010;135(4):149-54.

32. Nagase $\mathrm{K}$, Inoue $\mathrm{T}$, Narisawa $\mathrm{Y}$. Manifest hair repigmentation associated with etretinate therapy. J Dermatol. 2017;44(3):e34-e5.

33. Seckin D, Yildiz A. Repigmentation and curling of hair after acitretin therapy. The Australasian journal of dermatology. 2009;50(3):214-6.

34. Tengattini V, Lambertini M, Negosanti M, Piraccini BM, Patrizi A. Hair darkening after treatment with acitretin followed by narrow-band UVB. Clinical Dermatology. 2015;3(4):116-9.

35. Vesper JL, Fenske NA. Hair darkening and new growth associated with etretinate therapy. J Am Acad Dermatol. 1996;34(5 Pt 1):860.

36. Wang Z, Coleman DJ, Bajaj G, Liang X, Ganguli-Indra G, Indra AK. RXRa ablation in epidermal keratinocytes enhances UVR-induced DNA damage, apoptosis, and proliferation of keratinocytes and melanocytes. The Journal of investigative dermatology. 2011;131(1):177-87.

37. Ward PD, Miller HL, Shipman AR. A case of repigmentation and curling of hair on acitretin therapy. Clinical and experimental dermatology. 2014;39(1):91-2.

38. Philip M, Samson JF, Simi PS. Clofazimine-induced Hair Pigmentation. Int J Trichology. 2012;4(3):174-5

39. Kavak A, Akcan Y, Korkmaz U. Hair repigmentation in a hepatitis $\mathrm{C}$ patient treated with interferon and ribavirin. Dermatology. 2005;211(2):171-2.

40. Terheggen F, Frissen J, Weigel H, Schouten I, Brinkman K. Nail, hair and skin hyperpigmentation associated with 
indinavir therapy. AIDS (London, England). 2004;18(11):1612.

41. Belum VR, Benhuri B, Postow MA, Hellmann MD, Lesokhin AM, Segal NH, Motzer RJ, Wu S, Busam KJ, Wolchok JD, et al. Characterisation and management of dermatologic adverse events to agents targeting the PD-1 receptor. European journal of cancer (Oxford, England : 1990). 2016;60:12-25.

42. Dika E, Patrizi A, Ribero S, Fanti PA, Starace M, Melotti B, Sperandi F, Piraccini BM. Hair and nail adverse events during treatment with targeted therapies for metastatic melanoma. European journal of dermatology : EJD. 2016;26(3):232-9.

43. Hofmann L, Forschner A, Loquai C, Goldinger SM, Zimmer L, Ugurel S, Schmidgen MI, Gutzmer R, Utikal JS, Göppner $\mathrm{D}$, et al. Cutaneous, gastrointestinal, hepatic, endocrine, and renal side-effects of anti-PD-1 therapy. European journal of cancer (Oxford, England : 1990). 2016;60:190-209.

44. Hwang SJ, Anforth R, Carlos G, Fernandez-Peñas P. Cutaneous Adverse Events of New Anti-melanoma Therapies: Classification and Management. Actas dermosifiliograficas. 2017;108(1):6-16.

45. Hwang SJ, Carlos G, Wakade D, Byth K, Kong BY, Chou S, Carlino MS, Kefford R, Fernandez-Penas $P$. Cutaneous adverse events (AEs) of anti-programmed cell death (PD)-1 therapy in patients with metastatic melanoma: A singleinstitution cohort. J Am Acad Dermatol. 2016;74(3):45561.e1.

46. Hwang SJE, Fernández-Peñas P. Adverse Reactions to Biologics: Melanoma (Ipilimumab, Nivolumab, Pembrolizumab). Current problems in dermatology. 2018;53:82-92

47. Dummer R. Clinical picture: hair repigmentation in lentigo maligna. Lancet. 2001;357(9256):598.

48. Inzinger M, Massone C, Arzberger E, Hofmann-Wellenhof R. Hair repigmentation in melanoma. Lancet. 2013;382(9899):1224

49. Oza VS, Schulman JM, Mully TW, Ortiz S. A case of hair repigmentation from a scalp melanoma. Dermatology online journal. 2015;21(7).

50. Rahim R, Husain A, Tobin DJ, Lawrence C. Desmoplastic melanoma presenting with localized hair repigmentation. 2013.

51. Tiger JB, Habeshian KA, Barton DT, Brennick JB. Repigmentation of hair associated with melanoma in situ of scalp. J Am Acad Dermatol. 2014;71(4):e144-5.

52. Fernandez-Flores A, Manjon JA. Repigmentation of gray hair in lesions of annular elastolytic giant cell granuloma. Cutis. 2015;96(1):E19-22.
53. Li H, Fan L, Zhu S, Shin MK, Lu F, Qu J, Hou L. Epilation induces hair and skin pigmentation through an EDN3/EDNRB-dependent regenerative response of melanocyte stem cells. Sci Rep. 2017;7(1):7272.

54. Dinh HV, Sinclair R, Martinick J. Long-term hair repigmentation following a hair transplant for frontal scarring alopecia. The Australasian journal of dermatology. 2007;48(4):236-8.

55. Adiga GU, Rehman KL, Wiernik PH. Permanent localized hair repigmentation following herpes zoster infection. Arch Dermatol. 2010;146(5):569-70.

56. Comaish S. White scalp hairs turning black--an unusual reversal of the ageing process. The British journal of dermatology. 1972;86(5):513-4.

57. Füessl HS. [White hair turns brown]. MMW Fortschritte der Medizin. 2013;155(20):34

58. Navarini AA, Trüeb RM. Reversal of canities. Arch Dermatol. 2010;146(1):103-4.

59. Pattier P. [Spontaneous repigmentation of white hair]. Annales de dermatologie et de venereologie. 2001;128(10 Pt 1):1082-3.

60. Bellandi S, Amato L, Cipollini EM, Antiga E, Brandini L, Fabbri P. Repigmentation of hair after latanoprost therapy. Journal of the European Academy of Dermatology and Venereology : JEADV. 2011;25(12):1485-7.

61. Lajevardi V, Ghodsi SZ, Goodarzi A, Hejazi P, Azizpour A Beygi S. Comparison of systemic mycophenolate mofetil with topical clobetasol in lichen planopilaris: a parallel-group, assessor- and analyst-blinded, randomized controlled trial. Am J Clin Dermatol. 2015;16(4):303-11.

62. Razi-Khosroshahi M, Sobhani S, Yousefi KM, Harooni G, Mashayekhi F, Balasi J, Goodarzi A. Latanoprost in treatment of alopecia areata and androgenic alopecia: A comprehensive review. Pakistan Journal of Medical and Health Sciences. 2021;17(4):1535.

63. Roohaninasab M, Goodarzi A, Ghassemi M, SadeghzadehBazargan A, Behrangi E, Najar Nobari N. Systematic review of platelet-rich plasma in treating alopecia: Focusing on efficacy, safety, and therapeutic durability. Dermatol Ther. 2021;34(2):e14768.

64. Torabi P, Behrangi E, Goodarzi A, Rohaninasab M. A systematic review of the effect of platelet-rich plasma on androgenetic alopecia of women. Dermatol Ther. 2020;33(6):e13835.

65. MOODI $F$, BEHRANGI E, ROOHANINASAB M, SADEGHZADEH-BAZARGAN A, KHOSRAVI S, GOODARZI A. A Comprehensive Review on Trichogram and Trichoscopy in Dermatology.1576 P J M H S Vol. 15, NO. 5, MAY 2021 DOI: https://doi.org/10.53350/pjmhs211551576 